\title{
UVODNIK
}

\section{STRATEŠKE KOMUNIKACIJE IN OBOROŽENE SILE}

Druga številka v enaindvajsetem letu izhajanja Sodobnih vojaških izzivov je namenjena strateškim komunikacijam in njihovemu vplivu, povezavam in interakcijam, povezanim z oboroženimi silami. Morda ste že opazili, da uporabljamo izraz komunikacije, in ne komuniciranje. Na hitro bo marsikdo pomislil, da gre za majhno nepomembno razliko $\mathrm{v}$ besedah in besedni zvezi, saj med strateškim komuniciranjem in strateškimi komunikacijami ne more biti prav velike razlike, drugi bodo spet menili, da je raba ene ali druge oblike napačna. Terminološkega konsenza ni ne $\mathrm{v}$ slovenščini ne $\mathrm{v}$ angleščini. Na podlagi mnenja Inštituta za slovenski jezik Frana Ramovša ${ }^{1}$ v slovenščini uporabljamo v tej številki v kontekstu Natovega koncepta izraz strateške komunikacije. Pri tem poudarjamo, da z izborom izraza ne normiramo rabe, temveč si predvsem prizadevamo za doslednost in spodbujanje razprave. Iz člankov v številki razberemo, da si bo za terminologijo še treba prizadevati in da to ne bo preprosto. Nekateri sicer menijo, da je nepomembno usmerjati pozornost na drobne terminološke razlike, saj je vendar pomembna vsebina oziroma vse tisto, kar nam razvoj neke vsebine prinaša. Pa je res tako?

Pri pripravi tematske številke, ki je pred vami, smo se s številnimi izzivi srečali že pri načrtovanju. Temeljna zamisel je bila nameniti nekaj pozornosti komunikacijam in komuniciranju oboroženih sil z različnimi notranjimi in zunanjimi ciljnimi javnostmi v različnih oblikah, kot so na primer klasični mediji, socialna omrežja, različni javni dogodki, uporaba sile in podobno. Za oborožene sile je zelo pomembno, kakšna so razmerja znotraj sil, torej med zaposlenimi, in kakšna so razmerja z drugimi javnostmi, ki o delovanju in prihodnosti oboroženih sil tudi odločajo. Da bi dosegli kar najboljši rezultat, smo se povezali s prof. dr. Marjanom Malešičem s Fakultete za družbene vede Univerze v Ljubljani, ki je med drugim

Dostopno na https://isjfr.zrc-sazu.si/sl/terminologisce/svetovanje?keys=strategic + communications\#v. 
tudi dolgoletni vodja delovne skupine za področje odnosa javnosti in množičnih medijev do vojske pri evropskem združenju ERGOMAS, ki proučuje razmerja med vojsko in družbo.

Nismo ostali samo pri terminološkem vprašanju, temveč smo se ukvarjali tudi s pojmovnim. O temi, ki smo se ji posvetili, je veliko napisanega in ima vsebinsko bogato zgodovino. Med najpogostejšimi izrazi v njeni zgodovini so propaganda (ta je najstarejši), odnosi z javnostmi, informacijsko vplivanje, komuniciranje, strateško komuniciranje, korporativno komuniciranje in strateške komunikacije ter drugi. Ti so kot pojmi zapisani v Natovem konceptu strateških komunikacij, v katerem lahko preberemo, da gre za usklajeno in namensko uporabo njegovih informacijskokomunikacijskih zmogljivosti in dejavnosti. Sem spadajo dejavnosti javne diplomacije, odnosov z javnostmi ter informacijskega in psihološkega delovanja. Te so primerna podpora politiki, operacijam in delovanju zavezništva za doseganje ciljev Nata. Republika Slovenija je že petnajst let članica zavezništva. Slovenska vojska je ves ta čas močno vpeta $\mathrm{v}$ različne Natove dejavnosti in tudi zanjo velja Natov koncept strateških komunikacij. Zaradi navedenega je naslov tematske številke pred vami Strateške komunikacije in oborožene sile.

Pojmovni in terminološki vidik sta samo dva izmed številnih vidikov proučevanja izbrane teme, ki je interdisciplinarna in trenutno zelo pomembna. S svojih hitrim razvojem prinaša veliko priložnosti, vendar tudi vprašanj. Možnosti za raziskave, razprave in različne rešitve bo v prihodnje še veliko.

V članku Strategic communication(s) - kakšna je razlika? Iris Žnidarič predstavlja težave s pojmi, ki izhajajo iz različne rabe edninskega in množinskega samostalnika »communication « in »communications«, pri tem je poudarek na angleškem jeziku. Za izhodišče je avtorica vzela Natov koncept strateških komunikacij in predstavila rabo pojmov v posameznih teorijah, pri avtorjih in institucijah, ki se s tem področjem ukvarjajo. Dogovora o terminološkem poenotenju še ni, je pa veliko razlogov za to, da bi soglasje vendarle dosegli.

Legitimnost delovanja oboroženih sil je zelo pomembna. O tem, kakšen vpliv imajo socialni mediji nanjo in na švicarsko vojsko, pišejo Eva Moehlecke de Baseggio, Olivia Schneider in Tibor Szvircsev Tresch v članku Vpliv komunikacije na družbenih medijih na legitimnost oboroženih sil. Dejavnosti na Instagramu so začeli leta 2017 in že izvedli raziskavo o njihovi učinkovitosti. O njihovih ugotovitvah več v članku.

Nina Raduha se je v prispevku Strateške komunikacije kot priložnost voditeljev Nata in držav članic Nata posvetila konceptu Natovih strateških komunikacij s poudarkom na pomembni vlogi in odgovornosti voditelja oziroma poveljnika pri uveljavljanju, usmerjanju, sooblikovanju, izvajanju in spremljanju kakovosti izvajanja koncepta strateških komunikacij, ki predstavlja enega najpomembnejših orodij vsake moderne 
organizacije pri spoprijemanju s sodobnimi varnostnimi izzivi. Dvomov o tem, ali imeti StratCom ali ne, ni več, voditelj pa ima pri tem odločilno vlogo.

Informacijsko bojevanje je ena od oblik strateških komunikacij, trdi Glen Segell v članku Informacijsko bojevanje z mehko in trdo močjo: primer Izraela in Hamasa. Avtor pojasnjuje, da Hamas kot nevladna organizacija v Izraelu uporablja trdo obliko moči, Izrael pa uporablja mehko obliko moči v informacijskem vojskovanju znotraj strateških komunikacij v Gazi.

Nekateri pripadniki oboroženih sil po koncu mednarodnih operacij in misij napišejo knjigo o svojih izkušnjah. O tem, kakšne so te izkušnje in kakšno je sporočilo avtorjev, piše Esmeralda Kleinreesink pod naslovom Vojaške avtobiografije: jih spodbujati, odsvetovati ali prezreti? Za raziskavo je preučila primere avtorjev del, ki so pisali o svojih izkušnjah v Afganistanu.

Paul Ellis in Ric Cole sta osredotočena na socialna omrežja in njihove poglavitne sestavine. O tem, kaj je tisto, na kar mora biti pozorna vsaka organizacija, ki želi strateško komunicirati, in vse oborožene sile, ki želijo prek strateških komunikacij doseči svoje strateške, a tudi povsem operativne cilje, si preberite v članku Potreba po dejavnejšem sodelovanju in boljših komunikacijah v svetu, v katerem vlada stalna konkurenca.

Upamo in si želimo, da smo s to tematsko številko prispevali k razvoju, razumevanju ter implementaciji in opozorili na pomembnost obravnavane teme, ki je poglavitnega pomena za delovanje v sodobnem varnostnem okolju. 
